\title{
СУЧАСНІ МЕТОДИ ВИКЛАДАННЯ ФАРМАЦЕВТИЧНОЇ ХІМІЇ
}

\author{
Запорізький державний медичний університет
}

\author{
О. В. Кривошей
}

\section{MODERN METHODS OF PHARMACEUTICAL CHEMISTRY TEACHING}

\author{
O. V. Kryvoshey
}

\author{
Zaporizhian State Medical University
}

\begin{abstract}
Прагнення наблизити національний стандарт освіти до рівня загальносвропейського стандарту вищої освіти шляхом впровадження Болонського процесу мотивує професорсько-викладацький склад кафедри фармацевтичної хімії Запорізького державного медичного університету впроваджувати інтерактивні методи навчання. Одними з методів, які добре зарекомендували себе і використовуються на наших заняттях, $є$ методи “мозкового штурму”, “дискусіі”, ролеві ігри тощо.

Considering intention for harmonizing of national educational standards with European standards of pharmaceutical higher education by implementation of Bologna process, the professors and teachers of Pharmaceutical Chemistry Department of Zaporizhian State Medical University has introduced the interactive teaching methods. Among the methods that showed great advantage and commonly used in our classes are "brainstorm”, “discussion”, role-playing games.
\end{abstract}

Вступ. Серед дисциплін, освоєння яких дає можливість випускникам фармацевтичних факультетів вищих навчальних закладів (ВН3) одержувати посади провізорських спеціальностей, фармацевтична хімія є однією з найбільш необхідних.

Згідно з робочим навчальним планом та відповідними наказами Міністерства охорони здоров'я України [1, 2], по закінченню навчання провізор 3 дипломом спеціаліста галузі знань 1202 "Фармація” зі спеціальності 7.12020101 “Фармація” може працювати в аптеці, на аптечному складі, фармацевтичній фірмі, фармацевтичному виробничому підприємстві, у науково-дослідній установі, контрольно-аналітичних, наукових, судово-медичних експертних лабораторіях та виконувати такі види економічної діяльності:

- виробництво фармацевтичних препаратів;

- хімік-аналітик у сфері фармації;

- науковий співробітник;

- завідувач лабораторії з контролю виробництва;

- завідувач аптеки тощо.

Слід зазначити, що при вивченні фармацевтичної хімії у ВНЗ студенти протягом всього процесу навчання засвоюють методи виробництва ліків природного та синтетичного походження, методи та методики контролю якості лікарських засобів. Водночас студенти повинні засвоїти накази, які (c) О. В. Кривошей регламентують відповідну економічну фармацевтичну діяльність. Слід зазначити, що випускники фармацевтичних факультетів ВНЗ з успіхом займаються науковою діяльністю і працюють викладачами у навчальних закладах.

Основна частина. В теперішній час для найбільш повного засвоєння курсу дисципліни “Фармацевтична хімія” студенти користуються такими підручниками та навчальними посібниками [3-8]. В Запорізькому державному медичному університеті всі лабораторно-практичні заняття починаються з тестового контролю знань студентів за кожною темою заняття, для чого кафедра фармацевтичної хімії забезпечена зручним комп’ютерним класом. Навчальні лабораторії оснащені мультимедійним демонстраційним обладнанням, що дозволяє викладачам під час проведення занять надавати студентам у мультимедійному варіанті основні положення теми, яка вивчається, що, безумовно, сприяє кращому засвоєнню теоретичних знань та формуванню практичних навичок майбутнього фахівця.

Наявність сучасних підручників та навчальних посібників, з нашої точки зору, є гарним підгрунтям для повного засвоєння курсу дисципліни “Фармацевтична хімія”. Але беручи до уваги необхідність складання студентами Державного ліцензійного іспиту “Крок-2. Фармація” та бажання наблизити національний стандарт освіти до рівня загально- 
європейського стандарту вищої освіти шляхом впровадження Болонського процесу [9, 10], професорсько-викладацький склад кафедри фармацевтичної хімії Запорізького державного медичного університету запровадив використання інтерактивних методів при різних видах навчання.

3 нашої точки зору, для підвищення рівня засвоєння знань $з$ дисципліни необхідні передусім високий професіоналізм викладача, а саме достатній рівень науково-теоретичних знань не тільки у сфері фармацевтичної хімії, але й орієнтація в сучасних досягненнях, наукових відкриттях фармацевтичної галузі, а також високий рівень практичної, тобто педагогічної майстерності (знання сучасних і ефективних педагогічних методик та методів навчання). В останній час інтерактивне проведення занять $€$ одним з провідних способів надання навчального матеріалу студентам та оптимізації навчання.

Одним із методів, який добре зарекомендував себе і використовується на наших заняттях, є метод “мозкового штурму”. Як відомо, метод мозкового штурму є спробою пошуку рішення проблеми за допомогою стимулювання творчої активності [11]. Фармацевтична хімія як точна наука вимагає чіткості, логіки та точного мислення. Таким чином, при активізації максимального числа студентів за час проведення заняття підвищується якість засвоєння матеріалу теми заняття.

Наприклад, на лабораторно-практичному занятті, присвяченому вивченню лікарських засобів похідних карбонових кислот аліфатичного ряду, викладач зі студентами розглядає будову двох функціональних груп окремо: карбонільної і гідроксильної та їх взаємодію у складі карбоксильної групи, а саме виникнення р-л-кон'югації. У даному випадку шляхом дискусії викладач разом зі студентами прогнозують хімічні властивості, беручи до уваги навчальний матеріал по кетонах, альдегідах, спиртах, карбонових кислотах, розглядає зі студентами особливості УФ- та ІЧ-спектрів відповідних сполук, що є здійсненням міждисциплінарних зв’язків фармацевтичної хімії з аналітичною, органічною хімією, передбачає будову ароматичних (бензойна) та аліфатичних (цитратна тощо) кислот. Таким чином, на занятті використовуються методи “мозковий штурм” та “дискусія”.

На лабораторно-практичних заняттях, присвячених вивченню лікарських засобів - похідних гетероциклічних сполук, застосовуючи дані наукової літератури, студентам надається можливість спрогнозувати хімічні властивості та, звідси, запро- понувати можливі методи ідентифікації та кількісного визначення відповідних лікарських речовин, виходячи з їх будови. Корисним на таких заняттях $€$ міні-лекція у формі діалогу зі студентами із мультимедійним супроводженням з презентацією формул окремих представників лікарських засобів гетероциклічної будови.

Оскільки основним способом подання теоретичного матеріалу залишається лекція, існують різні підходи до її проведення. Але кожного разу лекція $є$ інтерактивним способом викладання, як найбільш ефективний спосіб засвоєння студентами певного розділу курсу фармацевтичної хімії.

При проведенні так званої проблемної лекції, наприклад за темою “Лікарські засоби з групи алкалоїдів”, спочатку перед студентами ставляться питання, проблеми, які вони мають вирішити разом із викладачем. Побудова структурних формул алкалоїдів, методи їх одержання, реакції ідентифікації, виходячи з аналізу функціональних груп i хімічних властивостей речовин, що вивчаються, все це, вже на етапі закінчення зазначеної теми, студент за допомогою викладача повинен вміти виконувати. Лекція, що проводиться у формі діалогу 3 аудиторією, у межах так званого “педагогічного співробітництва”, дає гарні результати засвоєння студентами теоретичного матеріалу.

Вивчення електронних ефектів, різних перегрупувань у молекулах, утворення побічних продуктів реакцій тощо не виключає проведення і практичних занять у формі “диспутів”. Викладач має навчити студентів прогнозувати логічним шляхом хід реакції, розуміти ії механізм із врахуванням засвоєного матеріалу. При виконанні практичної частини занять можливо застосування ролевих ігор, що передбачає елемент перевтілення студента у представника певної соціальної гри, професії тощо, наприклад, “На робочому місці провізора-аналітика аптеки”, “В контрольно-аналітичній лабораторії”, “У відділі технічного контролю фармацевтичного підприємства”. Таким чином студенти мають можливість відчути себе спеціалістами з різних видів фармацевтичного контролю якості лікарських засобів, відпрацювати комунікативні навички та уміння.

Важливими є педагогічні здатності викладача, такі, як комунікативність, доброзичливість та товариськість, перцептивні здатності - професійна проникливість, емпатія, педагогічна інтуїція, динамізм особистості - спроможність до вольового впливу та логічного переконання, які грунтуються на знаннях і досвіді, авторитеті викладача. 
Використання методу “ролевих ігор” також може підійти до вирішення практичних проблем на заняттях. Наприклад, при розгляді лікарських засобів, що мають у своїй будові конденсовану гетероциклічну структуру індол (індометацин, індапамід тощо), в академічних групах обговорюються проблеми реакційної здатності молекул із врахуванням їх будови, пошук більш екологічних та економічних варіантів одержання цих лікарських субстанцій i, як підсумок частини даного заняття - дебрифінг, у якому беруть участь студенти і викладач, який, спостерігаючи за темою обговорення від початку та за ідеями, які виникали в процесі обговорення, підбиває підсумок, висловлює заключне резюме.

На підсумковому модульному контролі достатньо ефективно можна використовувати рольові ігри на прикладі розгляду вивчених раніше лікарських засобів - похідних ароматичних та гетероциклічних сполук із різною кількістю гетероатомів у циклі, що включені до робочої програми з дисципліни “Фармацевтична хімія”. Кожна академічна група розглядає на прикладі речовин із певними функціональними групами їх будову та властивості, передбачає способи одержання і доводить свою правоту. У даному диспуті беруть участь студенти і викладач.

Можливість проявити вміння аналітично мислити та творчу активність студенти одержують при підготовці до захисту курсових робіт, що відбувається на останніх заняттях з фармацевтичної хімії на 3 та 4 курсах. Студенти мають довести свою спроможність розв'язувати професійні ситуації, проблеми, вирішення яких знаходиться на стику “різних хімій”: неорганічної, органічної, аналітичної, фармацевтичної, наприклад, курсова робота по розробці аналізу певної комбінованої лікарської форми. Обов'язковими розділами такої роботи є характеристика хімічної будови компонентів лікарського засобу, надання всіх можливих варіантів аналізу лікарської форми та обгрунтована пропозиція найбільш оптимального варіанта ідентифікації та визначення кількісного вмісту діючих речовин з урахуванням їх сумісної наявності в лікарському засобі. Захист курсової роботи відбувається в присутності студентів-однокурсників, викладачів і $€$ ко- рисним досвідом формування навичок привселюдного виступу. Крім того, студенти можуть проявити свої індивідуальні творчі здібності при розробці мультимедійних презентацій своїх доповідей, набути додаткових навичок роботи з комп'ютерними програмами написання хімічних формул органічних та неорганічних речовин, як ChemDraw, ISIS/ Draw, ChemSketch, ChemOffice тощо.

Достатньо ефективними $є$ лекції або лабораторно-практичні заняття із розглядом різних професійних ситуацій, із запропонованими хибними формулами, визначеннями, можливими механізмами реакцій, що дає можливість максимально збільшити увагу студентів, заохотити їх до пізнавальної діяльності. Студенти самі повинні проаналізувати матеріал, знайти помилки та виправити їх.

Таким чином, використання інтерактивних методів при викладанні дисципліни “Фармацевтична хімія” дає позитивні результати засвоєння теоретичних знань з предмета й підвищує якість практичних вмінь та навичок студентів. Крім того, допомагає формуванню додаткових важливих у майбутньому професійному житті якостей випускників. Так, студенти мають можливість одержати досвід культури ведення дискусії; вчаться вміння відстоювати свою думку та приймати спільні рішення, працювати “в команді” на результат; вдосконалюють вміння доповідати. Інтерактивні методи навчання зміщують сприйняття навчального матеріалу на якісно інший рівень. Студентам стає цікаво не просто запам'ятовувати інформацію, а намагатися розібратися в ї̈ суті, щоб використати в практичній частині заняття, а далі і в практичній сфері профеciї. У зв'язку з цим студенти мають бути впевнені у необхідності одержуваних на заняттях знань, їх значимості, що є важливим мотивуючим фактором до навчання.

Висновки: 1. Розробка інтерактивних методів навчання набуває значної популярності серед викладачів та студентів.

2. Встановлена ефективність використання інтерактивних методів і методик у навчальному процесі при засвоєнні теоретичних знань та формуванні практичних навичок з фармацевтичної хімії.

2. Про затвердження переліків закладів охорони здоров'я, лікарських, провізорських посад та посад молодших спеціалістів з фармацевтичною освітою у 
закладах охорони здоров’я : наказ МОЗ України від 28.10.2002 р. № 385.

3. Туркевич М. М. Фармацевтична хімія / М. М. Туркевич, О. В. Владзімірська, Р. Б. Лесик. - Вінниця : Нова Книга, 2003. - 464 с.

4. Туркевич М. М. Фармацевтична хімія / М. М. Туркевич. - К. : Вища школа, 1973. - 495 с.

5. Безуглий П. О. Фармацевтична хімія / П. О. Безуглий. - Вінниця : Нова книга, 2006. - 552 с.

6. От субстанции к лекарству / [П. А. Безуглый, В. В. Болотов, И. С. Гриценко и др.]. - Х. : Изд-во НфаУ : Золотые страницы, 2005. - 1244 с.

7. Фармацевтична хімія [П. О. Безуглий, І. В. Українець, В. О. Грудько та ін.]. - Х. : Вид-во НФАУ, Золоті сторінки, 2002. - 448 с.
8. Безуглий П. О. Фармацевтичний аналіз / П. О. Безуглий, В. О. Грудько, С. Г. Леонова. - Х. : Вид-во НФАУ, Золоті сторінки, 2001. - 240 с.

9. Болонський процес у фактах і документах (Сорбонна - Болонья - Саламанка - Прага - Берлін) / [М. Ф. Степко, Я. Я. Болюбаш, В. Д. Шинкарук та ін.]. - Тернопіль : Вид-во ТДПУ ім. В. Гнатюка, 2003. - 52 с.

10. Вища освіта України і Болонський процес. Навчальна програма. - К. ; Тернопіль : Вид-во ТДПУ ім. В. Гнатюка, 2004. - 18 с.

11. Малахова Ж. Д. Викладання соціології: досвід інноваційних прийомів / Ж. Д. Малахова, В. М. Огаренко. - Запоріжжя, 2006. - 280 с. 